\title{
Feeding value of shrimp waste meal for West African Dwarf sheep fed soybean stover basal diet
}

\author{
B.O. Oduguwa ${ }^{1 *}$ and I.F. $\mathrm{Adu}^{2}$ \\ 'Research and Development Centre, University of Agriculture, Abeokuta, P.M. B. 2240, Nigeria \\ 'College of Animal Science and Livestock Production, University of Agriculture, Abeokuta, \\ Nigeria. \\ *Corresponding author e-mail: oduguwa2002 Ryahoo.com
}

\begin{abstract}
A degradability and feeding trial was carried out to estimate the utilization of soybean stover (SBS), Shimp waste meal (SWM) and their mixtures (SBS+SWM) in West African Dwarf sheep. Sole samples of SBS. SWM and mixture of SBS+SWM were incubated in the rumen of castrated West African Dwarf rams. Degradation lasted 48 hrs. Feeding trial entailed feeding graded levels $10 \%, 5 \%$, $10 \%, 15 \%$ ) of SWM to a sole SBS diet. The growth study lasted for eight weeks. Results obiained in - the degradability trial showed that there were significant $(p<0.05)$ differences in the dry matter (DM), crude protein (CP), neutral detergent fibre (NDF) and acid detergent fibre (ADF) degradability parameters for the feedstuffs. The effective DM degradability ' $E D$ ' was highest in SBS $(343.0 \mathrm{~g} / \mathrm{kg})$ and lowest in $S W M(250.0 \mathrm{~g} / \mathrm{kg})$. Crude protein effective degradability 'ED' ranged between 101.0 and $301.0 \mathrm{~g} / \mathrm{kg}$ for SBS and SBS+SWM respectively. NDF 'ED'ranged between $398.6 \mathrm{~g} / \mathrm{kg}$ for SWM and $815.7 \mathrm{~g} / \mathrm{kg}$ for SBS. ADF degridation characteristics for the constituents were also significantly $(P<0.05)$ different with the soluble fraction ' $a$ 'values ranging between 126.0 and $624.0 \mathrm{~g} / \mathrm{kg}$. When graded levels of shrimp waste meal was used as supplement to soybean stover, there were significant $(P<0.05)$ differences in the average daily weight gain, which ranged from 9.52 to $22.85 \mathrm{gd}^{-t}$. The mean live weight gain was highest at $10 \%$ level of inclusion. Average daily DM intake decreased significantly $(P<0.05)$ with increasing level of SWM in the diet. The sole soybean stover diet however had the least DMI. DM, OM, NDF and ADF apparent digestibility coefficients were not significantly affected by the treatment imposed. $C P$ digestibility increased $(P<0.05)$ with increasing level of SWM to peak at the 15\% level of inclusion (0.766) compared to the sole SBS treatment (0.593). Nitrogen balance was significantly $(P<0.05)$ increased as the level of inclusion of SWM increased. Results stggest that feeding soybsan stover as roughage along with up to $10 \%$ SWM to sheep may be sufficient to meet the requirements for weight gam and proper mutrient utilization.
\end{abstract}

Key words: Degradability, soybean stover, shrimp waste meal, sheep 


\section{Introduction}

Shrimp waste meal has generated a lot of interest as animal protein source in Nigeria. There is a significant amount of waste generated from the shrimp industry because large percentage of its head, exoskeleton and soluble components are lost during the various processing operations (Fanimo et al., 1996). The increase in shrimp farming in Nigeria has led to the concomitant production of shrimp waste. Significantly large amount of shrimp are sold as peeled or unpeeled tail after cropping, beheading and washing. Shrimp waste meal is basically the dried milled waste of shrimp industry consisting of the head, appendages and exoskeleton of the shrimp (Fanimo et al., 1996). Crustacean waste has been incorporated in the diets of growing lambs to comprise of $35-40 \%$ of protein intake (Bunting et al., 1994) to realize a positive growth response. SWM can partially or totally replace the use of soybean in livestock feed (Rosenfeld et al. 1997). However, chitin a homopolymer of $\mathrm{N}$ acetyl-P-D glucosamine joined together by $\mathrm{b}$ ( 1 4) glycosidic linkage is abundant in the exoskeleton of the shrimp (McDonald et al., 1998). This chitin is similar to cellulose, which is also a structural material. There is possibility, therefore, of providing two sources of protein one directly through the production of protein and other indirectly through a bioconversion process of the chitin to produce single cell protein (Freer et al., 1996). The use of protein sources whose nutrient escapes rumen degradation improves considerably the performance of the animais. As forages are deficient in ruminally degradable protein, supplementation strategies should maximize microbial protein production in the rumen in order to enhance production. Previous works indicated that shrimp byproducts have intrinsic properties useful for mono-gastric animals (Oduguwa et al., 1998. Toan and Ngoan, 2003, Fanimo et al., 2004). However, little work has been done on its use in feeding sheep. This study was therefore designed to provide insight into the ruminal degradability characteristics and performance of sheep fed sundried shrimp waste meal as a supplement.

\section{Materials and Methods Degradability Studies \\ Experimental site}

The study was carried out at the International Livestock Research Institute (ILRI) farm in Ibadan, South-Western Nigeria. The station is located between latitude $6^{\circ} 10$ North and longitudes $3^{\circ}$ and $6^{\circ}$ East. The vegetation in this area is made up of derived guinea savanna and humid forest zone (Ezenwa, 1995) and mixed farming had been practiced in the area for several decades.

\section{Animals and their management}

Three West Aftican Dwarf castrated rams about 2 years old, tagged 150,160 and 170 with an initial live-weight of 24,25 and $26 \mathrm{~kg}$ respectively, were used for the studies. Each animal was under' general anaesthesia fitted with permanent cannula ( $75 \mathrm{~mm}$ internal diameter) in the dorsal sac of the rumen. Each animal was kept in separate pen ( $3 \mathrm{~m} \times 2.5 \mathrm{~m})$ where there was a free access to water and trace mineralized salt lick daily. They were also allowed to graze freely occasionally in the paddock grown with 
Panicum maximum grass. They wete fed with cowpea husk and sorghum residue with water $a d$ libiium. The area of the cannulae was cleaned regularly.

\section{Experimental diets}

The samples used for the degradability study were soybean stover (SBS), Shrimp waste meal (SWM) and mixture of SBS+SWM (in ratio 8:2 basis).

\section{Determination of degradation characteristics}

The DM degradability of the samples was determined using the nylon bag technique (Orskov et al., 1980). The samples were ovendried at $60^{\circ} \mathrm{C}$ to constant weight and the dry weight taken. Samples were then ground through a laboratory hammer mill with a $2.0 \mathrm{~nm}$ screen size. About $5 \mathrm{~g}$ of each feed was weighed into nylon bags (pore size $40-50$ micron ìm). Each bag was then inserted into the rumen of the animals through the cannula. Bags were attached to carrier weight to prevent them from floating above the rumen contents. The incubation pcriod was $6,12,24$ and 48 hours. The 48 -hour samples were the first to be inserted followed by 24,12 and 6 hours respectively. The bags were removed at the same time from the rumen at the end of incubation period. They were then, together with those not subjected to any rumen fermentation representing $0 \mathrm{hr}$ washed under running tap water at $37^{\circ} \mathrm{C}$ for 30 minutes until the water colour became clear. All washed bags and their contents were placed on metal trays and oven dried at $60^{\circ} \mathrm{C}$ for 48 hours in forced air oven, cooled in a desiccator and weighed to determine DM loss.
Disappearance of DM was measured as the loss in weight of the bag content. The results were fitted to the exponential equation.

$\mathrm{P}=\mathrm{a}+\mathrm{b}\left(\mathrm{I}-\mathrm{e}^{\mathrm{ct}}\right)$ (Orskov and McDonald, 1979), where $P=D M$ degraded $(\mathrm{g} / \mathrm{kg}$ ) from the bag after time ' $t$ ' (hr), a - the intercept of the degradation curve at time zero that is the soluble fraction. $b-$ The portion of the sample which will in time ' $t$ ' be degraded, $c=$ The rate constant for the degradation of ' $b$ ', $t=$ time of degradation $(a+b)=$ the potential extent (asymptote) of degradation.

$\mathrm{ED}=$ effective degradability $=\mathrm{a}+\mathrm{bc} /(\mathrm{c}+\mathrm{k})$

Where $\mathrm{k}$ is rumen out flow rate of $2 \% \mathrm{~h}^{-1}$

The effective degradability (ED) was estimated according to the method of Mc Donald (1981).

\section{Chemical analysis}

Dry matter (DM) of the samples was determined by drying in an oven at $60^{\circ} \mathrm{C}$ to constant weight ground through a $1 \mathrm{~m}$ screen and used for chemical analysis. Nitrogen concentration was analysed by the Kjeldahl method (A.O.A.C, 1990) and crude protein content was calculated (N*6.25); Cell Wall disappearance was estimated by determining neutral detergent fibre (NDF) and Acid detergent fibre (ADF). Neutral detergent fibre (NDF), acid detergent fibre (ADF), acid detergent lignin (ADL) were measured by methods of Goering and Van Soest (1970). Ash was the residue after ashing the samples at 550$600^{\circ} \mathrm{C}$. Chitin was determined according to Stelmock et al. (1985). Gross energy of the samples was determined with adiabatic bomb calorimeter. 
Siatistical analysis

A completely randomized design for DM, N and $\mathrm{NDF}, \mathrm{ADF}, \mathrm{ADL}$ degradation was applied. AIl data were subjected to analysis of variance (ANOVA), Statistical Analysis System (SAS) 1 1989).

\section{Trial 2}

Description of study site

The study was conducted in the Experimental Unit, Small Ruminant Section of the College of Animal Science and Livestock Production (COLANIM) Teaching and Research farms, Lniversity of Agriculture, Abeokuta (South Western Nigeria), which falls under the derived savanna transition zone. The altitude of the region is of 70 meters above sea level and falls within latitudes $7^{\circ} 5-7^{\circ} 8$ and longitudes $3^{\circ} 11.2$ $-3^{0} 2.5^{\prime} \mathrm{E}$. The climatic condition is humid with a mean annual rainfall of $1037 \mathrm{~mm}$. The annual mean temperature and humidity are $34.7^{\circ} \mathrm{C}$ and $82 \%$ respectively.

\section{Experimental diet preparation}

The soybean (Glycine max Merrill) stover (mixed varieties) used in the study was procured from the University of Agriculture, Abeokuta (UNAAB), model extension villages. They were threshed with Vogel type mechanical thresher obtained from IITA, Ibadan. The stover was thereafter subjected to further deseeding process, to ensure the pods were properly stripped of the raw seeds which is detrimental to the animals. It was spread out and sun dried for 7 days. After drying the stover were baled into bundles in jute bags and stored in a well -ventilated room till required for feeding. All stover collected were fed to the sheep as threshed.
Experimental animals and their management

Twelve West Dwarf (WAD) sheep were used for this study. The animals were about 7-9 months old with mean body weight of $14.51 \pm 0.15 \mathrm{~kg}$. They were randomly allocated to four experimental treatments of 100:0, 95:5, 90:10, $85: 15$ graded levels of soybean stover (SBS) and Shrimp waste meal (SWM). Weighed SBS and SWM were offered to animals in separate feed troughs twice a day, at 0800 and 1600 hours in equal proportion such that each animal received a quantity amounting to recommended daily allowance of $50 \mathrm{~g} \mathrm{DM} / \mathrm{kg} \mathrm{LW} /$ day. Growth and dry matter intake study lasted for eight weeks. The animals were transferred into metabolic cages at the end of eight weeks for the digestibility study which lasted for 7 days. The sheep were housed in individual metabolism crates where the quantity of feed intake, faecal and urinary output were monitored over the period, during which $10 \%$ aliquot of the total faeces and urine were bulked and kept for chemical analysis of the proximate components. Determination of the different components in the feed, faeces and urine was through the standard method of analysis as described in Trial 1.

All data generated were subjected to analysis of variance in a completely randomised design using general linear models procedure (SAS, 1989). The mean separation was done using the Duncan Multiple Range Test (Duncan, 1955)

\section{Results}

\section{Chemical composition of samples}

Both soybean stover and shrimp waste meal had similar levels of DM, OM and gross energy, while 
shrimp waste meal contained twice the level in CP. The Neutral detergent fibre (NDF), Acid detergent fibre (ADF) and lignin contents were higher in soybean stover (SBS) than in SWM (Table 1). Soybean stover had a crude protein content of $92.6 \mathrm{~g} / \mathrm{kgDM}$, NDF of $703 \mathrm{~g} / \mathrm{kg} \mathrm{DM}$, ADF of $542.7 \mathrm{~g} / \mathrm{kg}$ DM and lignin content of $245.0 \mathrm{~g} / \mathrm{kg}$ DM. Shrimp waste meal had a crude protein content of $273.4 \mathrm{~g} / \mathrm{kg} D M$, a NDF value of $422.8 \mathrm{~g} / \mathrm{kg}$ DM, $\triangle \mathrm{DF}$ of $437.7 \mathrm{~g} / \mathrm{kg}$ DM and lignin cóntent of $21.0 \mathrm{~g} / \mathrm{kg} \mathrm{DM}$.

The dry matter degradability characteristics for the samples depicted that the soluble fraction $(\mathrm{P}<0.05)$ ranged from 155.1 in shrimp waste meal to 251.9 in soybean stover and the degradable fraction ( $P>0.05$ ) ranged from 105.3 in SBS and 109.4 in mixture. (Table 2)

There were significant $(\mathrm{P}<0.05)$ differences in the degradability characteristics of crude protein. (Tables 3). Effective degradability (ED) of crude protein was generally low with a range of 101.0 in SBS and $301.1 \%$ in SBS+SWM. The CP degradability characteristics of the feedstuffs differed in water solubility $(33.1-134.7)$, rate of degradation $(6.0$ to $8.0 / \mathrm{h})$ and lag time $(39.0$ to $65.0 \mathrm{~h})$.

The NDF degradability of the feedstuffs also differed $(\mathrm{P}<0.05)$ significantly in water solubility, with values ranging from 267.6 to 785.6 . The rate of degradation of the degradable fraction ranged from 4.85 to 9.0 per hour. There was a distinct superiority in this constant in soybean stover over the other feeds. Moreover, effective degradability (ED) was highest in SBS followed by SBS+SWM (Table 4 )
Performance, nutrient intake, nitrogen utilization and digestibility of WAD sheep fed graded levels of SWM

Total weight gain of the animals increased progressively with increasing level of inclusion of SWM up to $10 \%$ beyond which the weight gain declined (Table 6). Daily weight gain ranged from 9.52 to $22.85 \mathrm{gd}^{-1}$ for sole SBS and $10 \%$ SWM treatments respectively.

Treatments had significant influence $(P<0.05)$ on the nutrient intakes of DM, OM, CP $\left(\mathrm{gd}^{-1} \mathrm{~W}^{07}\right)$. Total DM intake was highest at $5 \%$ shrimp waste meal inclusion. The lowest DM intake was recorded in the sole soybean stover diet. The intake of CP increased slightly as the inclusion of SWM increased. However, the sole feed of stover significantly reduced in CP intake resulting in a significant difference among the treatments.

Apparent digestibility coefficient values were high generally and did not show any much variation among the treatments, except for crude protein digestibility which was lowest in the sole soybean stover diet. Dry matter digestibility value ranged between 0.738 and 0.7460 for $10 \%$ SWM and SBS diets respectively. Crude protein digestibility values ranged between 0.593 and 0.766 . Organic matter digestibility values ranged between 0.761 and 0.802 . The fibre fractions (ADF and NDF) did not show significant differences across treatments (Table 6).

Nitrogen intake increased but not significantly ( $>0.05)$ among the diets as the level of SWM inclusion increased. Sole SBS treatment induced the lowest nitrogen intake in the sheep which ranged from 7.32 to 10.78 
Table 1: Proximate composition of soy bean stover and shrimp waste meal.(g/kg)

\begin{tabular}{|c|c|c|}
\hline Constituents & Soybean stover & Shrimp waste meal \\
\hline Dry matter & 942.6 & 844.7 \\
\hline Organic matter & 919.0 & 921.9 \\
\hline Crude protein & 92.6 & 273.4 \\
\hline Ash & 81.0 & 178.1 \\
\hline Neutral detergent fibre & 703.0 & 422.8 \\
\hline Acid detergent fibre & 542.7 & 437.7 \\
\hline Acid detergent lignin & 245.0 & 23.0 \\
\hline Cirosscnergy (Kcal/g) & 4.64 & 3.2 \\
\hline Chit in & - & 111.0 \\
\hline
\end{tabular}

Table 2: Dry matter degradability coefficients of soybean stover (SBS), shrimp waste meal (SWM) and mixture of $S B S+S W \mathrm{~V}(\mathrm{~g} / \mathrm{kg})$ in the rumen of West A frican D warf sheep

\begin{tabular}{|c|c|c|c|c|c|}
\hline & Sosbean siover & $\begin{array}{l}\text { Shrimp } \\
\text { nucal }\end{array}$ & waste & $\begin{array}{l}\text { Soybean stover } \\
\text { Shrinp waste meal }\end{array}$ & $+\quad \mathrm{SEM}$ \\
\hline i1 & $2519^{2}$ & $155.1^{\circ}$ & & (1) $7.0^{6}$ & 0,14 \\
\hline h & 105.3 & 109.1 & & 109.4 & 0.02 \\
\hline p & $351.7^{\mathrm{h}}$ & $264.2^{\mathrm{C}}$ & & $373.0^{\circ}$ & 0.43 \\
\hline c & $1.29^{6}$ & $1.34^{3}$ & & $1.0^{\mathrm{c}}$ & 0.01 \\
\hline Lag time & 27.3 & 27.3 & & 310 & 0.25 \\
\hline $\mathrm{ED}$ & $343.0^{\mathrm{a}}$ & $250.0^{\mathrm{f}}$ & & $310.0^{b}$ & 3.56 \\
\hline
\end{tabular}

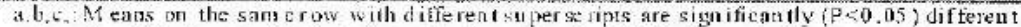

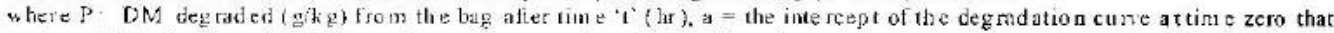
is the soluble fraction. $b=T$ he portion af the sample which will in the ' $t$ ' be degraded, $e=$ The rate eoustant for the degrad ation of $b^{\prime} \cdot t=$ tire of degrad ation

$(a-b)=$ the potential exlent lasyngtotel of depradation

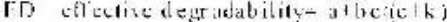

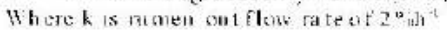


Table 3: ( rudz protein degradability coefticients of soybean stover (SBS), slurimp waste meal (SWM and mixture of $S B S+S W M(\mathrm{~g} / \mathrm{kg})$ in the rumen of W est A frican D warf sheep

\begin{tabular}{|c|c|c|c|c|}
\hline & Soybean stover & $\begin{array}{c}\text { Shrimp swaste } \\
\text { meal }\end{array}$ & $\begin{array}{l}\text { Soybean stover } \\
+ \\
\text { Shrimp waste meal }\end{array}$ & SEM \\
\hline a & $34.9^{6}$ & $134.7^{\circ}$ & $33.1^{26}$ & 1.62 \\
\hline$b$ & $85.2^{\text {ib }}$ & $88.6^{\circ}$ & $28.3^{c}$ & 0.11 \\
\hline $\mathrm{p}$ & $120.1^{\mathrm{b}}$ & $223.3^{a}$ & $61.4^{c}$ & 1.79 \\
\hline $\mathrm{c}$ & $6.5^{b}$ & $6.0^{c}$ & $8.0^{\text {it }}$ & 0.01 \\
\hline lag lime & $39.0^{\mathrm{c}}$ & $46.7^{b}$ & $65.0^{2}$ & 0.19 \\
\hline ED & {$[0] .0^{\circ}$} & $201.1^{\mathrm{l}}$ & $301.0^{\mathrm{a}}$ & 1.62 \\
\hline
\end{tabular}

Table 4: Neatual detergent tibre degradability coellicients of soybean stover (SBS), shrimp waste meal (SWM) and mixture of SBS+SWM (g/kg) in the rumen of West African dwarf sheep

\begin{tabular}{|c|c|c|c|c|}
\hline & Soybean stover & $\begin{array}{c}\text { Shrimp waste } \\
\text { meal }\end{array}$ & $\begin{array}{c}\text { Soybean stover } \\
+ \\
\text { Shrimp waste meal }\end{array}$ & SEM \\
\hline a & $785.6^{\mathrm{a}}$ & $267.6^{\circ}$ & $398.6^{6}$ & 0.62 \\
\hline $\mathrm{b}$ & $37.5^{\mathrm{b}}$ & $49.5^{\mathrm{a}}$ & $28.1^{\circ}$ & 0.11 \\
\hline$p$ & $823^{4}$ & $317.4^{\circ}$ & $610^{b}$ & 1.79 \\
\hline$C$ & $8.3^{2}$ & $4.85^{b}$ & $9.0^{\mathrm{n}}$ & 0.11 \\
\hline latg time & $42.7^{\mathrm{b}}$ & $65.0^{4}$ & $21.0^{\mathrm{c}}$ & 0.38 \\
\hline ID & $815.7^{\mathrm{a}}$ & $3009^{\circ}$ & $453.1^{h}$ & 1.62 \\
\hline
\end{tabular}

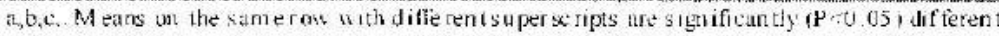

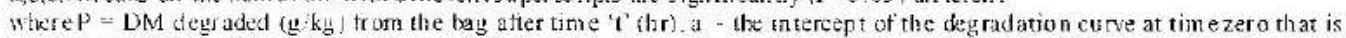
the soluhle traction, $b=$ The portion of the sample which will in time ' $t$ ' be degrated, $c=$ The $r$ ate constant for the degratdation of " $b^{\prime}, t=$ time of dega adation

$(a+b)=$ the potental extost (asimptore) of degradation

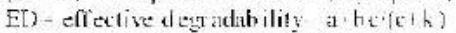

Where $k$ is rumen out tow rate of $2^{\text {a }}$ eh $^{-1}$ 


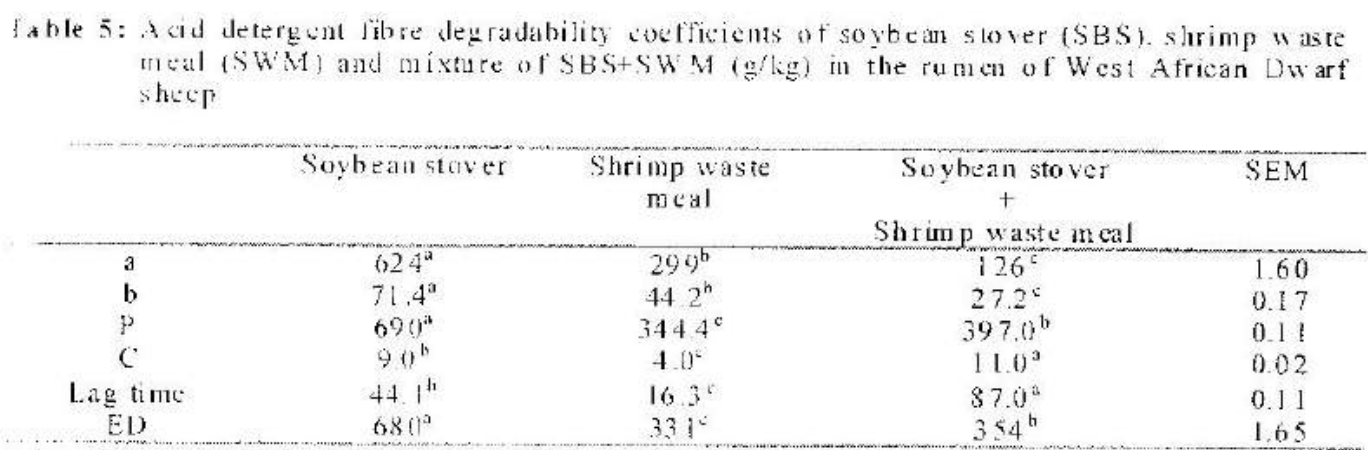

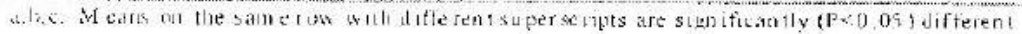

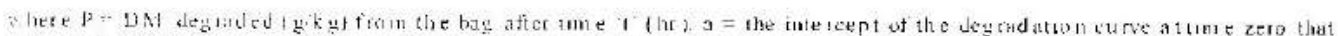

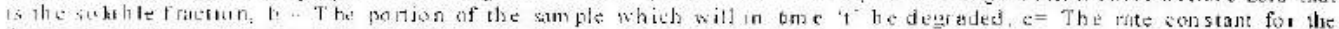

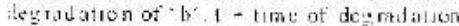

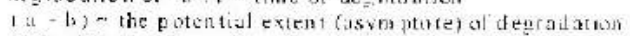

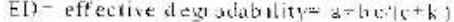

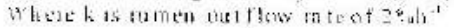

Table 6: Nutrient intihe perlonname and apparent digestibility coefticients of West African Ditarl sheep feel graded levels of Shrimp waste meal (SWM) and soybean stover as basal feed

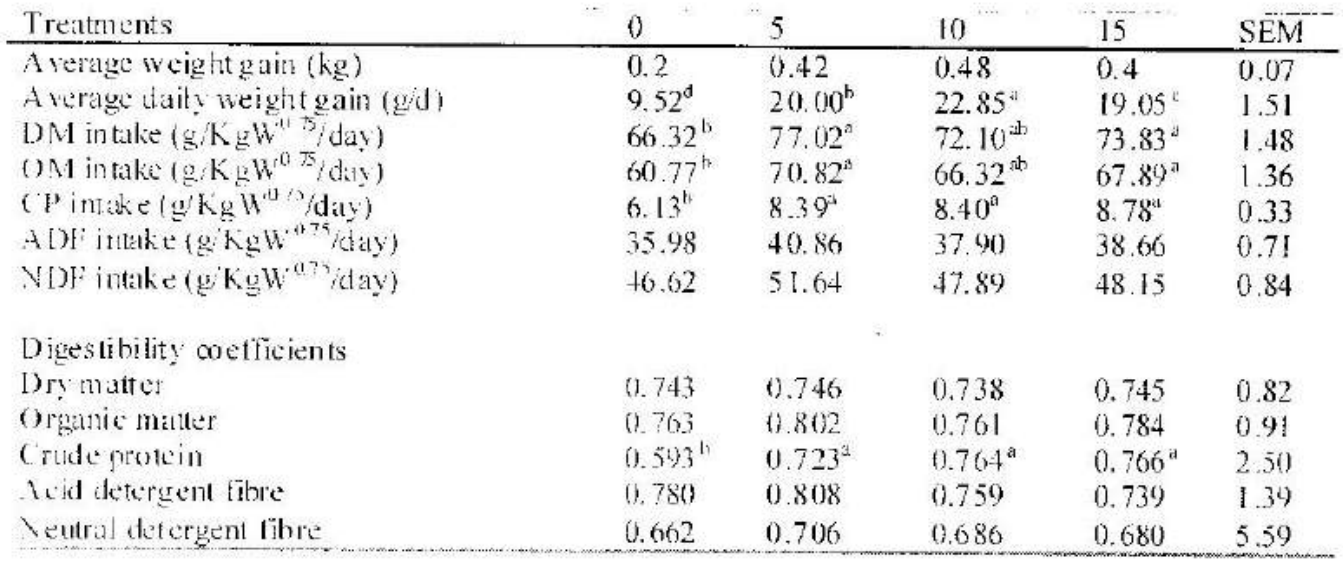

a.h.c.d: Wearus on the same row with diterent superseripts are significantly (P<0.05) diflerent 
Table 7: Nitrogen utilization by West African Dwarf sheep fed graded levels of Shrimp waste meid (SWM) using soy bean stover as the basal feed

\begin{tabular}{|c|c|c|c|c|c|}
\hline \multirow[t]{2}{*}{$\overline{\text { Parameters }}$} & \multicolumn{5}{|c|}{ Treatments } \\
\hline & () & 5 & 10 & 15 & SEM \\
\hline Nitrogen in take $(\mathrm{g} / \mathrm{d})$ & $7.32^{6}$ & $10.04^{\mathrm{a}}$ & $10.7^{a}$ & $10.78^{a}$ & 0.42 \\
\hline$N$ in take (g/d/W kg $\left.{ }^{075}\right)$ & 0.98 & 1.39 & 1.34 & 1.40 & 0.12 \\
\hline Faecal Noutput ( $\mathrm{g} /$ day) & 2.35 & 1.89 & 1.69 & 1.77 & 0.11 \\
\hline Urinary $N$ output ( $\mathrm{g} /$ day $)$ & $0.76^{\mathrm{b}}$ & $1.69^{a}$ & $1.62^{\circ}$ & $1.43^{a}$ & 0.12 \\
\hline Total N output (g/day) & 3.11 & 3.58 & 3.31 & 3.20 & 0.14 \\
\hline Nitrogen retained ( $g /$ day) & $4.17^{\circ}$ & $6.45^{6}$ & $7.05^{\text {ab }}$ & $7.60^{\mathrm{a}}$ & 0.0 .1 \\
\hline Nitrogen-retent ion (\%) & $57.17^{\mathrm{b}}$ & $64.26^{\text {th }}$ & $68.14^{3}$ & $69.36^{x}$ & 1.84 \\
\hline
\end{tabular}

a.. ah. h.: Means on the same row with different superseripts are significantly $(P<0.05)$ different

$\left(\mathrm{gd}^{-1}\right)$ (Table 7$)$. The urinary $\mathrm{N}$ output decreased as the level of inclusion increased while faecal nitrogen output was highest in the animals fed sole SBS with a range of $1.69-2.35\left(\mathrm{gd}^{-1}\right)$. Increase in the level of shrimp waste meal increased the level of $\mathrm{N}$ retained, with the sole feed significantly lower than the others. The values of the percent nitrogen retained ranged from $57.17 \%$ to $69.36 \%$. It followed the same trend as $\mathrm{N}$ retention above.

\section{Discussion}

The crude protein content of the shrimp waste meal (SWM) is lower than $395 \mathrm{gkg}^{-1}$ reported by Fanimo et al. (2004) and $397 \mathrm{~g} \mathrm{~kg}^{-1}$ by Oduguwa et al. (2000). The reason for the low crude protein value could be due to the variation in the proportion of components of the waste, the source or processing methods used or the storage agge.

The dry matter composition of the shrimp waste used in this study was expectedly so as it was collected and sun cured before the feeding trial commenced. The composition of shrimp waste varies with the proporion of shrimp heads to shells and the type of processing. The crude protein content of the shrimp waste used in this study is lower than $33.4 \%$ reported by Evers and Carroll (1998). This can be adduced to the reasons stated above. Also storage of the meal may also be a factor for contributing to the differences in CP. The energy and ash values obtained are quite moderate for an animal protein source. The ash content is about twice the content in SBS, probably due to high exo-skeleton content of the meal which is mainly made of minerals. This value is lower than $39.2 \%$ (Abazinge et al., 1993) for crab waste meal. NDF and Acid detergent fibre were higher than 22.2 and $17.0 \%$ reported by Abazinge et al. (1993) for crab waste meal.

The protein requirement for growing sheep as recommended by ODNRI (1988) is between 12 and $13 \%$. The CP content of the experimental dicts as determined were adequate for meeting the requirementof the animals since it is still within the recommended range. NDF content was higher than ADF content in all the feedstuffs. 
Crude protein disappearance was low in all the feedstuffs used. The low effective degradation (ED) of $\mathrm{CP}$ for the feeds may be as a result of some factors. The nylon bag data indicated that approximately $10 \%$ of the original crude protein (CP) in the feedstuff samples disappeared in the rumen. This may infer that at $48 \mathrm{hr}$ most of the nitrogenous materials were not degradable.

The low CP effective degradation in SWM indicated a very slow adaptation of ruminal microorganism to diets containing chitinous compounds. This is congruent with the reports by Cobos et al. (2002). The rate of degradation (c) in this study $\left(0.060 \mathrm{~h}^{-1}\right)$ was higher than $0.014 \mathrm{~h}^{-1}$ reported for chitin (Fadel El-Seed et al., 2002). Though chitin is degradable in the rumen, it may not be an effective resource for ruminant feed. Chitin might have exerted some adverse effect on the fermentation of SWM. The microflora may not be adapted to SWM which is an animal product.

Lower CP content of proximate composition was reported for feed mixtures when compared with their sole feed counterpart. This adversely affected the effective degradability (ED) of crude protein, which was further lowered than the sole feed. It can be explained that the basal feed (soybean stover) negatively affected the CP characteristics by diluting the nitrogen release adversely. The significantly increased lag time indicated that the rumen microbes did not colonise the feed adequately. The generally low CP degradation in the mixtures of the feed-stuffs is in sharp contrast to the findings of Flachowsky and Schnider (1992), who reported that feed combinations of straw/concentrate were enhanced from 42.3 to $66.9 \%$ when concentrate component of straw/ concentrate mixtures increased from 20 to $80 \%$. However, it has a bearing with Akinlade et al. (2001) report that mixture of rice stover and A. cordifolia had a depressive effect on the soluble fraction of the feeds. The type of protein source seems to influence the CP degradability characteristics, though the values were generally low. Rooney (1997) reported differences in the combining ability for protein degradability in alfalfa, recording relative ratio of additive to nonadditive effects ranging from 0.86 for crude protein, 0.70 for soluble protein, 0.74 for insoluble protein, and 0.80 for proportion of undegradable insoluble protein/insoluble protein. Therefore within different combinations there will be negative or positive associative effects. Moreover, it could be that the proportion of bound $\mathrm{N}$ in form of ADF-N, NDF-N is high, this could adversely affect the degradability of the components because most Acid detergent insoluble- $N(A D F-N)$ is resistant to microbial and mammalian enzymes (Huhtanen and Hristov, 2001).

The values obtained in the present study for shrimp waste cannot be compared with $0.03 / \mathrm{h}$ reported by Evers and Carrol (1998). This may be due to the differences in the process of estimation used. Morphological fraction might have affected fibre degradation in the diets. This is due to the high (a) fraction for NDF and ADF above the other feed-stuffs.

It also compares favourably with the reports of Orden et al. (2000) who stated that degradation parameters for NDF were not affected by supplementing rice straw with rice bran in sheep and ADF potential degradability 
when two types of protein, soybean meal and fish meal were fed as supplements to Panicum maximum grass.

The dried shrimp waste meal used in this study is not very palatable when fed as sole ingredient in the diets. As the inclusion level increased, total dry matter intake decreased at the expense of the shrimp waste meal. Although, slight improvements in feed intake have been reported for cattle fed crayfish-crustacean waste meals (Velez et al., 1991), cattle fed crab-based crustacean waste meal have generally been observed to eat less than those fed soya-bean meal (Brundage et al., 1984; Laflamme, 1988; Velez et al, 1991).

In this study increasing the level of shrimp waste meal in the diets did not influence the total $C P$ intake among the diets. There were no observed differences in the intakes of NDF, ADF. The inclusion of SWM improved the liveweight gain of sheep fed on these diets as opposed to the unsupplemented ones. SWM used in this study had presumably made their relative nutritional contribution in terms of animal protein requirement (Bunting et al., 1994). Therefore, it will be reasonable to assume that the observed reduction in the growth efficiency of sheep fed $15 \%$ SWM may be more related to the inefficient usage of feed protein in the form of chitin rather than to reduced organic matter fermentation. This assumption would support the studies of Velez et al. (1991) and Cobos et al. (2002) using crab waste and shrimp waste respectively.

Apparent digestibility of nutrients was generally high but best in supplemented diets. This observation is consistent with previous studies involving graded levels of shrimp shell waste fed to sheep (Cobos et al., 2002). The digestibility of the crude protein value obtained were higher than a range of 59.2 - 74.9 obtained by Ayangbile et al. (1998), though these workers fed crab waste -straw silage to sheep.

The $\mathrm{N}$ retention value was higher in the supplemented diet and reflected the potential of SWM to enhance $\mathrm{N}$ utilization. Nitrogen intakes increased linearly with increased levels of shrimp waste meal (Cobos et al., 2002). Faecal, urinary and total $\mathrm{N}$ excretion did not follow the trend above. Faecal $\mathrm{N}$ output was highest in the sole SBS diet as well as the least $\mathrm{N}$ urinary output. Van Soest (1982) stated that when the requirement of $\mathrm{N}$ is met, additional dietary $\mathrm{N}$ increases urinary $\mathrm{N}$ output. There was an observed reduction in $\mathrm{N}$ loss in the urine of animals on all the diets. The values of $\mathrm{N}$ retention, expressed as percentage of intake were similar in all the supplemented diets and also in agreement with Ayangbile et al (1998). The results of the study reveal that the feeding value of soybean stover can be enhanced with further supplementing with SWM. The potential of SWM however at levels higher than $10 \%$ may be detrimental to performance of the animal. With more efforts targeted at further research into processing treatments that could further degrade chitin in SWM, it may be possible to increase its feeding value for sheep.

\section{References}

A.O.A.C. 1990. Official Methods of Analysis. $15^{\text {th }}$ Edition. Association of Official Analytical Chemists, Washington D.C. pp $69-88$. 
Abazinge, M.D.A, J.P Fontenot and V.G. Allen, Flick, G.J. 1993. Ensiling characteristics of crab waste and wheat straw treated with different additives. $J$. Agric. Food Chem. 41:657-661.

Akinlade, J.A. Olanite, J.A. and Bamikole, M.A. 2001. Dry matter degradation characteristics of rice stover with different proportions of Ficus capenis or Alchornea cordifolia in rumen fistulated sheep, goats or cattle. Nig. J. Anim. Prod. 28 (2): 174 181.

Ayangbile, G.A. Fontenot, J.P. Graham, P.P, Kirk, D.J. and Allen, V.G. 1998. Nutrient utilization by sheep fed crab waste straw silages. J. Anim. Sci. 76: 686-693.

Brundage, A.L., Husby, F.M. Herlugson, M.L. Simpson, W.L. and Burton, V.L. 1984. Acceptability of tanner crab meal in concentrate for lactation. J. Dairy Sci., 67: $1965-1970$.

Bunting, L.D., Sticker, L.S, Kappel, L.C. and Zhang, Y. 1994. Growth responses and ruminal adaptation of lambs fed crustacean processing waste. Anim. Feed Sci. Technol. $45(3 / 4): 229-241$.

Cobos, M.A., Garcia, L.E. Gonzalez, S.S., Barcena, J.R., Hernandez, D.S. and Perez Sato,M. 2002. The effect of shrimp shell waste on ruminal bacterial and performance of lambs. Anim. Feed Sci. Tech. 95(3/4): $179-187$.

Duncan, D.G. 1955. Multiple range and multiple F-tests. Biometrics, $111-42$.

Evers, D.J. Carroll, D.J. 1998. Ensiling salt preserved shrimp waste with grass straw and molasses. Anim. Feed Sci. Technol. $71(3 / 4): 241-249$.

Ezenwa, I.V. 1995. Forage production potential of herbaceous and tree legumes in mixtures with grasses in Oyo State, Nigeria. Ph.D Thesis, Agronomy Dept.,University of Ibadan, Ibadan, Nigeria.

Fadel-El-Seed, A.N.M.A., Kamel, H.E.M., Sekine, J. Hishinuma, M and Hamana, K. 2002. Chitin and chitosan as possible novel nitrogen sources for ruminants. Can. J. Anim. Sci. 83: $161-163$.

Fanimo, A.O., Mudama, E., Umukoro, T.O. and Oduguwa, O.O. 1996. Substitution of shrimp waste meal for fish meal in broiler chick ration. Tropical Agriculture (Trinidad). 73(2):201-207.

Fanimo,A.O., Oduguwa, B.O., Oduguwa, O.O., Ajasa, O.Y. and Jegede, O. 2004. Feeding value of shrimp waste meal for 
growing pigs. Archivos de Zootecnia 53:7785

Flachowsky, G. and Schneider, M. 1992. Influence of various straw to concentrate ratio on in sacco dry matter degradability, feed intake and apparent digestibility in ruminants. Anim. Feed Sci. Technol. 34: 199 $-227$.

Freer,J., Paez,G., Marmol,Z., Ramones,E., Garcia,H and Forster,C.F. 1996. Acid hydrolysis of shrimp-shell waste and the production of single cell protein from the hydrolysis. Bioresource Technology 57(1):56-60.

Goering,H.K. and VanSoest, P.J. 1970. Forage fiber analysis. Apparaus, reagents, procedures and some applications. USDA

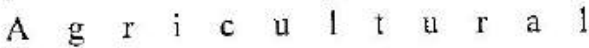
Handbook,397, WashingtonD.C. pp 1-20

Huhtanen, P and Hristov, A.N. 2001. Estimating the passage kinetics using fibre bound $15 \mathrm{~N}$ as an internal marker. Anim. Feed Sci. Technol 94 (1/2):29 - 41 .

Laflamme, L.F. 1988. Utilization of crab meal fed to young beef cattle. Can. J.Anim Sci 68: $1237-1244$.

McDonald,I. 1981. Revised model for the estimation of protein degradability in the rumen. J.Agric. Sci. (Camb.) 96:251-252.
McDonald, P., Edwards, R.A., Greenhaulgh, J.F.D. and Morgan, C.A. 1998. Animal Nutrition. $5^{\text {th }}$ Edition. Longman, Singapore Publishers (Pte) Ltd. Singapore: 607 pp.

ODNRI. 1988. The small-scale manufacture of compound animal feed. Overseas Development Natural Resources Institute. Bulletin No 9 Parr, W.H (Compiler) 87pp.

Oduguwa,O.O., Fanimo, A.O., Iyayi, E.A., Kalejaiye,O.O and O.A. Oyekola. 1998. Preliminary studies on the effects of different processing methods on the nutritivevalue of shrimp waste meal. Nig. J. Anim. Prod., 25:139-144.

Oduguwa,O.O., A.O.Fanimo., A.A. Onifade and A. Arije. 2000 . Nutritive value of shrimp waste-meal and fly larva meal (maggot meal) in growing albino rats. Indian J. Anim. Sci 70(1):70-72.

Orden, E.A, Yamaki, K, Ichinohe, T., Fujihara, T. 2000. Feeding value of ammoniated rice straw supplemented with rice bran in sheep:II In situ rumen degradation of untreated and ammonia treated rice straw. Asian-Australasian $J$. Anim. Sci 13 (7):906-912

Orskov, E.R. and MeDonald, I. 1979. The estimation of protein degradability in the 
rumen from incubation measurements weighted according to rate of passage. $J$. Agric Sci. 92: 499-503

Orskov,E.R., Hovell, F.D.Deb and Mould, F. 1980. The use of nylon bag techniques for the evaluation of feedstuffs. Trop. Anim. Prod. 5: 195-213

Rooney,W.L, Skinner, D.Z and Fritz, T.O. 1997. Combining ability for protein degradability in alfalfa. Crop Science 37(I): 128-131

Rosenfeld D.J., Gernat, A.G. Marcano, J.D., Murrilo, J.G, Lopez, G.N and Flores, J.A. 1997. The effect of using different levels of shrimp meal in broiler diets. Poultry Science. $76: 581-587$.

Statistics Analysis Systems Institute. 1989. SAS/STAT Users' Guide: Statistics, Version 6. $4^{\text {th }}$ Edition, Carey, North Carolina, USA. Pp 943.

Stelmock,R.L., Husby,F.H., Brundage,A.L,. 1985. Application of Van Soest acid detergent fibre method for analysis of shellfish chitin. J. Dairy Sci. 68: 15021506.
Toan, N.H. and L.D. Ngoan. 2003. Evaluation of shrimp by-products for laying hens in smallholder systems in Thua Thien Hue province. In: Proc. Final National SeminarWorksop on Sustainable Livestock Production on Local Feed Resources (Eds: R. Preston and B. Ogle). HUAF-SAREC. Hue city 25-28 March, 2003. Retrieved from $h t p / w w w . m e k a r n . o r g / s a r e c ~ 03 /$ toan.htm

Van Soest, P.J. 1982. Metabolic functions Nitrogen metabolism: Nutritional ecology of the ruminant. O.\& B Books. Corvallis, Oregon, USA.

Velez, S.A. Allen, J.C., Keery, C.M. and Atkinson, R.W. 1991. Evaluation of crab and cray fish waste as protein sources for growing dairy heifer. J. Dairy Sci. 74:234 -242 .

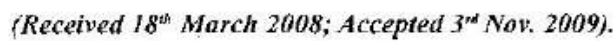

